\title{
Hydrological responses of a valley-bottom wetland to land-use/land-cover change in a South African catchment: making a case for wetland restoration
}

\begin{abstract}
Alanna J. Rebelo ${ }^{1,2,3}$, David C. Le Maitre ${ }^{4}$, Karen J. Esler ${ }^{1,5}$, Richard M. Cowling 6
Valley-bottom wetlands are valuable assets as they provide many ecosystem services to mankind. Despite their value, valley-bottom wetlands are often exploited and land-use/land-cover (LULC) change results in trade-offs in ecosystem services. We coupled physically based hydrological modeling and spatial analysis to examine the effects of LULC change on water-related ecosystem services in the Kromme catchment: an important water-providing catchment for the city of Port Elizabeth. LULC scenarios were constructed to match 5 different decades in the last 50 years to explore the potential effects of restoring the catchment to different historic benchmarks. In the Kromme catchment, valley-bottom wetlands have declined by $84 \%$, driven by key LULC changes: an increase in irrigated land ( $307 \mathrm{ha}$ ) and invasion by alien trees ( $336 \mathrm{ha})$. If the wetlands were restored to the relatively pristine extent and condition of the 1950s, riverflow could increase by approximately 1.13 million $\mathrm{m}^{3} / \mathrm{a}$, about $6 \%$ of the current supply to Port Elizabeth. Wetland restoration would also significantly improve the catchment's ability to absorb extreme rainfall events, decreasing flood damage. We conclude that in the face of the water scarcity in this region, all ecosystem services, particularly those related to water flow regulation, should be taken into account by decision makers in charge of land zonation. Zonation decisions should not continue to be made on the basis of provisioning ecosystem services alone (i.e. food provision or dam yield). We recommend prioritization of the preservation and restoration of valley-bottom wetlands providing water-related ecosystem services to settlements downstream.
\end{abstract}

Key words: baseflow, ecological infrastructure, ecosystem services, flood attenuation, invasive species, valley-bottom wetland

Implications for Practice

- Clearing alien invasive trees from naturally shrub-dominated valley-bottom wetlands decreases evapotranspiration, suggesting that this could be a viable management strategy to increase/restore riverflow.

- Agriculture in wetlands may cause destabilization and loss of the alluvium, resulting in permanent loss of water-related ecosystem services.

- Decision makers and managers faced with land zonation decisions have important trade-offs to consider between the suite of ecosystem services provided by wetlands (water provision and flood attenuation) and those provided by the agriculture that replace them (food provision).

- In cases where settlements downstream rely on the water-related ecosystem services of a catchment and where valley-bottom wetlands are intact, it may be beneficial for decision makers to consider zoning these catchments primarily for water provision.

\section{Introduction}

Wetlands across the globe are regarded as valuable because they provide society with many ecosystem services through the ability to slow down or temporarily retain water and sediments (Simonit \& Perrings 2011; Russi et al. 2013). Key water-related ecosystem services provided by wetlands include water flow regulation (sustaining baseflow or dry season flow, recharging of groundwater aquifers, flood attenuation) as well as nutrient and waste assimilation, which improves water quality (MEA 2005; Russi et al. 2013). There are many human and environmental driving forces that damage or change wetlands, and this affects their ability to effectively perform these functions (Nelson 2005). This study examines the impacts of land-use/land-cover (LULC) on water flow regulation (water provision and flood regulation) of the Kromme catchment.

LULC change has been identified as among the most important drivers of ecosystem transformation (Nelson 2005; Reyers et al. 2009). A change from one LULC type to another (e.g.

Author contributions: DLM, RMC, KJE, AJR conceived the study; AJR, DLM designed the research and conducted research/analysis; AJR, DLM wrote the manuscript; RMC, KJE edited the manuscript.

${ }^{1}$ Department of Conservation Ecology and Entomology, Stellenbosch University, JS Marais Building, Victoria Street, 7600 Stellenbosch, South Africa

${ }^{2}$ Ecosystem Management Research Group (ECOBE), Department of Biology, University of Antwerp, Office 2.20, Building C, Universiteitsplein 1, Wilrijk, 2610 Antwerp, Belgium

${ }^{3}$ Address correspondence to A. J. Rebelo, email ARebelo@sun.ac.za

${ }^{4}$ Council for Scientific and Industrial Research (CSIR), PO Box 320, 7600 Stellenbosch, South Africa

${ }^{5}$ Centre for Invasion Biology (C.I.B), Stellenbosch, South Africa

${ }^{6}$ Department of Botany, Nelson Mandela Metropolitan University, PO Box 7700, 6031 Port Elizabeth, South Africa

(C) 2015 Society for Ecological Restoration

doi: 10.1111/rec.12251

Supporting information at:

http://onlinelibrary.wiley.com/doi/10.1111/rec.12251/suppinfo 
wetland to agriculture) may result in trade-offs between ecosystem services where one service increases at the expense of another, or synergies where services increase or decrease simultaneously (Smith et al. 2013). As land globally becomes limited, there is greater emphasis on the optimal management of ecosystem service provision (Van der Biest et al. 2014). In terms of optimizing water-related ecosystem services, there are two key factors when considering LULC change: the change in structure of vegetation and the location of change. Changes in LULC from woody vegetation (e.g. a forest or riparian woodland) to pasture or crops are known to increase riverflow and therefore yield (Bosch \& Hewlett 1982; Scott et al. 2004; Scanlon et al. 2007). This results from changes in rainfall partitioning between evaporation and runoff at both habitat and landscape scales arising from differences in vegetation structure (Scott et al. 2004). The location of specific LULC changes within a catchment also plays an important role in the riverflow response, with riparian areas being particularly sensitive to change (Scott 1999; Everson et al. 2007).

In South Africa, LULC change due to the spread of invasive alien plants (IAP) threatens many riparian and wetland ecosystems, affecting water-related ecosystem service delivery. Models and measurements of the hydrological impacts of IAPs, especially woody trees in riparian zones, predict a decrease in riverflow (Le Maitre et al. 1996; Le Maitre \& Görgens 2001; Dye \& Jarmain 2004). By analogy with plantations, woody IAPs are also predicted to decrease groundwater recharge (Le Maitre et al. 1999), decrease total annual flow and baseflow (Scott \& Lesch 1997; Scott \& Smith 1997), and have a variable effect on stormflow, depending on the magnitude of the rainfall event and the degree of soil saturation (Vertessy et al. 2003; Scott et al. 2004). South Africa suffers from chronic water scarcity and water supplies from catchments are already over-committed (Ashton 2002). The ecological assets (e.g. wetlands or aquifers), of many of the country's important water-providing catchments are in a critical state ( $\mathrm{Nel}$ et al. 2007). Over $65 \%$ of these wetlands are described as threatened and half are estimated to have been destroyed (Nel \& Driver 2012). The Kromme River System in the Eastern Cape of South Africa is an example of a valuable water-providing catchment that has become degraded. The degradation was considered so severe that South Africa's two largest national rehabilitation programs selected this catchment when launched in 1995: Working for Water, which clears IAPs and Working for Wetlands, which rehabilitates wetlands (van Wilgen et al. 2012). However, the effects of IAP clearing and wetland rehabilitation on the delivery of water-related ecosystem services from the Kromme catchment have not been quantified.

We used a hydrological model to improve our understanding of how the LULC changes altered the hydrological responses of the landscape. The following question was addressed: what impact have key LULC changes (e.g. wetlands to agriculture) had on the water-related ecosystem services provided by the Kromme catchment? Two key water-related ecosystem services were investigated: water delivery (i.e. riverflow, with mean annual runoff [MAR] as an indicator) and flood attenuation (i.e. with percentage of rainfall yielded as runoff as an indicator).
A change from wetlands to another LULC (e.g. woody IAPs or irrigated agriculture) was predicted to reduce the riverflow component of the water balance by increasing evaporation losses. The subsequent loss of the irrigated lands and the alluvial sediments to erosion was predicted to decrease the water storage and retention capacity of the catchment. This, in turn would reduce the catchment's flood attenuation capacity, resulting in an increase in runoff response and more severe floods (Vörösmarty et al. 2005; Mander et al. 2010). Using historical LULC scenarios allowed us to track key LULC changes over time and investigate their associated hydrological impacts. We use this retrospective technique to predict whether restoration to past, more intact states could be expected to produce a significant improvement in water-related ecosystem services.

\section{Methods}

\section{Study Site}

The Kromme River $\left(33^{\circ} 52^{\prime} \mathrm{S}, 24^{\circ} 2^{\prime} \mathrm{E}\right)$ is located in the Eastern Cape Province of South Africa (Fig. 1). It is $100 \mathrm{~km}$ in length from its upper reaches ( $550 \mathrm{~m}$ above sea level) to its estuary. The catchment is narrow and steep, bordered by the Suuranys Mountains (approximately $1,050 \mathrm{~m}$ ) to the north, and the Tsitsikamma Mountains (approximately 1,500 m) to the south, both running approximately east-west. The Kromme River is divided into five quaternary subcatchments. This study focuses on the upper Kromme comprising the two uppermost subcatchments: K90A and K90B (Fig. 1). The rocks in the area comprise quartzitic sandstones (ridges and slopes) and softer sandstones and shales (valley bottom) of the Cape Supergroup.

The valley bottom is filled with a deep, alluvial deposit which was covered in wetlands in the mid-18th century (Skead 2009). These wetlands were dominated by Prionium serratum (Palmiet), a sedge-like plant which has a clumped above-ground structure and deep and extensive root systems (approximately $2.2 \mathrm{~m}$ long [Sieben 2012]) that capture and retain sediments and accumulate organic matter to form sandy peat deposits. It typically forms unchanneled or weakly channeled valley-floor wetlands (sensu Ollis et al. 2013). Most of these wetlands were converted to cultivation (largely post-1950), or P. serratum was shaded-out by IAPs, leaving few reasonably intact, unchanneled examples in the upper catchment (Figure S1, Supporting Information). The removal of extensive $P$. serratum beds to provide arable land exposed the underlying peats and alluvium to floodwaters eroding these deposits to form wide channels. In places, the down-cutting exceeds $5 \mathrm{~m}$ in depth and the width more than $100 \mathrm{~m}$.

The sandstones of the Cape Supergroup can be an important source of groundwater (Xu et al. 2009), but the quantity of water they yield is highly variable and depends largely on the presence of large fracture and fault systems to provide connectivity. Baseflow estimates for catchments K90A and K90B are relatively high: 7.5 million $\mathrm{m}^{3} / \mathrm{yr}$ or $24.9 \%$ of the MAR for K90A and 6.4 million $\mathrm{m}^{3} / \mathrm{yr}$ or $25.0 \%$ for K90B (Xu et al. 2009). However, there are no data on the proportion of the baseflow that is groundwater discharge-although it 

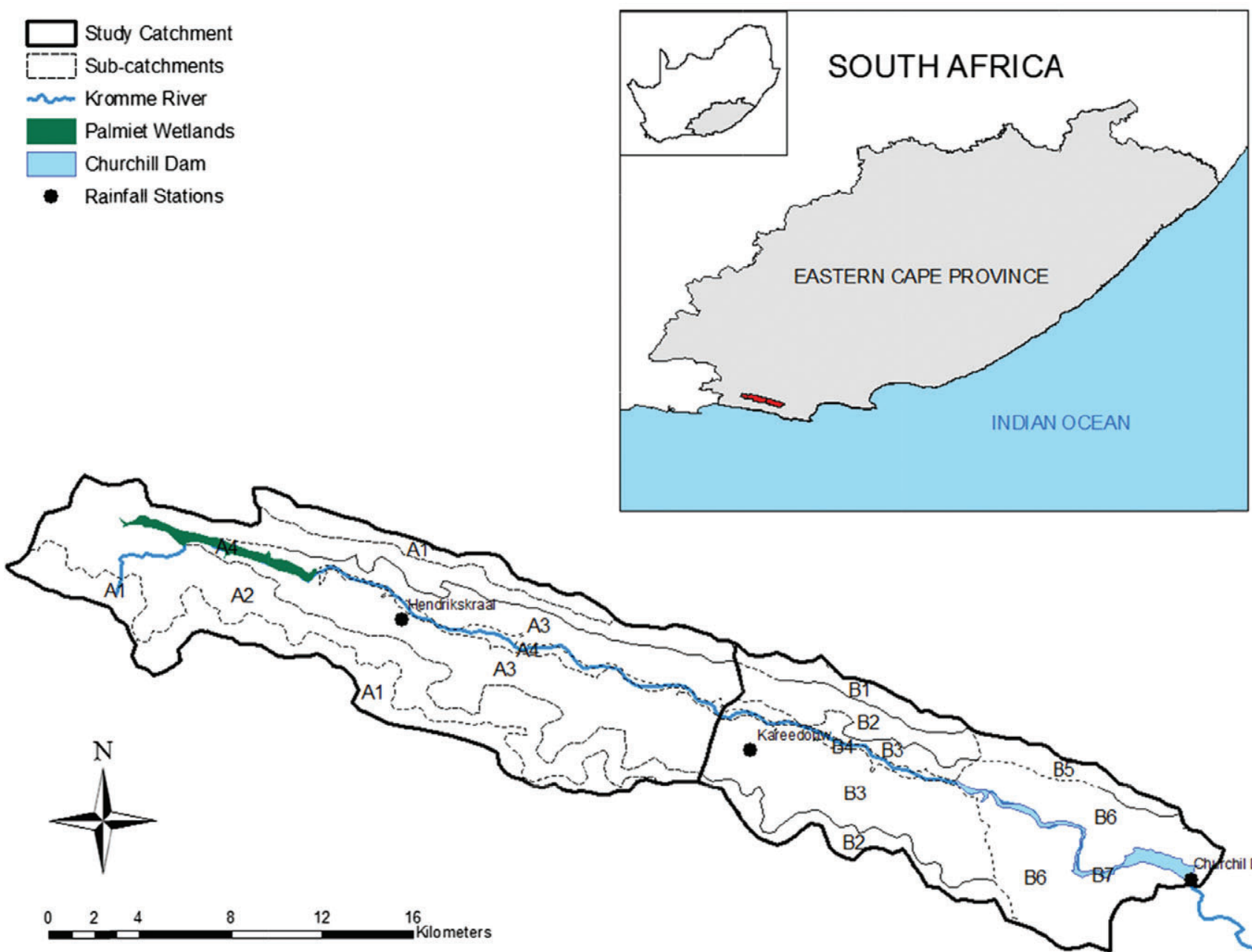

Figure 1. The location of the Kromme River study catchments (K90A [left] and K90B [right]) and the position of the Churchill Dam in the Eastern Cape Province of South Africa (inset). The upper Kromme was divided into 11 study subcatchments (A1-4, B1-7). The position of the three rainfall stations within the study catchments are marked by black circles. Units A4, B4, and B7 represent the alluvial environments.

is likely to be high - and what proportion is from storage in the hard rock aquifers in the sandstones versus the extensive and deep alluvial deposits. Nevertheless, the high baseflow proportions provide strong evidence that groundwater fluxes play a substantial role in the hydrology of this catchment, and that this must be considered in the analysis.

The Nelson Mandela Bay metropolitan hub includes one of South Africa's larger cities: Port Elizabeth. The city is experiencing critical water shortages and is seeking to increase its water supply and security of that supply (DWA 2010). It receives $40 \%$ of its water supply from the Kromme River with $24 \%$ drawn from the Churchill Dam which is fed by the upper Kromme alone.

Rainfall in the region is unpredictable, but generally exhibits a bimodal pattern, with peaks in spring and autumn (Midgley et al. 1994). Mean annual precipitation (MAP) for the catchment for the period from 1950 to 2000 is approximately $614 \mathrm{~mm}$. Pre-development MAR for the entire Kromme River catchment was modeled as approximately $75 \mathrm{~mm}$, which is approximately $11 \%$ of the rainfall (Middleton \& Bailey 2008). Reliable rainfall data, obtained from Lynch (2003), were only available up to 2000, which meant that the ACRU modeling could not continue beyond that year.

\section{Mapping LULC Scenarios}

The LULC scenarios used in this study are not "future possible developments," but represent historical "time slices" (periods). Four of the LULC scenarios were constructed for 1954, 1969, 1986, and 2007 using land-cover mapped at high resolution (approximately $5 \mathrm{~m}$ ) from 1:20,000 aerial photographs with a geographic information system (GIS) system (ESRI 2009). The fifth (pre-development) scenario was added for the flood attenuation analysis and was based on a reconstruction of the vegetation of the Kromme before European occupation (Skead 2009). Using "real" scenarios (i.e. a spatio-temporal approach using past land transition information) combined with data on environmental variables can lead to improved understanding 
of landscape dynamics over time (Iverson et al. 2014). In this case, the five scenarios capture the changes over time allowing for the hydrological effects of restoration to be explored. This approach avoids the problem of the long time frames needed to measure the effects of restoration, due to lag-effects (Hamilton 2012). Its weakness is that it assumes that it is possible to restore the area to its previous states (Moreno-Mateos et al. 2012).

\section{Using Hydrological Modeling to Investigate Impacts of LULC Change}

There are no accurate records of the riverflow in the Kromme River, the only measurements having being taken below the Churchill Dam. The inflows are estimated from changes in the reservoir water levels which are unreliable because small errors in the recording of the water level can result in large errors in the estimated inflow. Therefore, the best method of estimating the impacts of LULC changes on riverflow is to use a hydrological model. As we could not follow the normal practices of calibrating and testing the reliability of the model using observed riverflow (e.g. Jewitt \& Schulze 1999), we compared information on the modeled evaporation from key LULC classes with independent measures.

\section{The ACRU Agrohydrological Model}

The Agricultural Catchments Research Unit (ACRU) model was chosen because it has been extensively tested and validated under South African conditions (Schulze 1995; Jewitt \& Schulze 1999; Warburton et al. 2010), has a large database of vegetation and soil parameters developed for South African conditions, and because it is the appropriate scale for the catchment. It is a physical-conceptual model with a daily time step, based on multi-layer soil water budgeting. It is consequently sensitive to LULC changes, irrigation demand, and the onset and degree of water stress. We used default parameter values for most of the LULC types from a previous hydrological study of the catchments of Kromme, Kouga, and Baviaanskloof (Mander et al. 2010). However, this particular study used the new wetland and riparian routines of version four of the ACRU model, an extension that allows excess riverflow to flood adjacent riparian or wetland hydrological response units (HRUs; see Gray 2011 for model development).

The importance of groundwater in these catchments does complicate modeling because surface water models typically do not represent groundwater dynamics well and groundwater models do not represent LULC changes or the effects of groundwater access on vegetation water-use well and require detailed data on aquifer characteristics that are not available. The focus of the LULC change is, however, not on groundwater dynamics but on the key vegetation changes that occurred almost entirely in the alluvial environments where groundwater is within the rooting depth. The riparian routines of the ACRU model were developed specifically for such situations and so should capture the effects of groundwater availability on the ability of the plants to respond to evaporative demand.

\section{Model Set-up}

Subcatchments. The study catchment (subcatchments K90A and K90B) was sub-divided into 11 hydrologically distinct subcatchments (A1-4 and B1-7) (Fig. 1). The main factor guiding the delineation was altitude, because rainfall is positively correlated with altitude. Catchment responses to rainfall are non-linear, so a single mean rainfall value would not be an adequate driver of hydrological processes over the whole catchment. The subcatchments were based on those delineated by Schulze et al. (2008), as rainfall, geology, and soils had already been taken into account during this process. The subcatchments were further divided based on geomorphology, with three extra subcatchments delineated to represent the alluvial deposits and the associated valley-bottom wetlands.

Hydrological Response Units. The subcatchments, in turn, were divided into 15 different HRUs, which are areas of the subcatchment that are treated as a unit due to similarities in soil and vegetation, based on the LULC scenarios (Table 1). Fynbos (natural shrublands that occur mainly in the Cape Floristic Region

Table 1. The 15 land-use/land-cover classes of hydrological response units (HRUs) mapped in each of the subcatchments of the upper Kromme.

\begin{tabular}{lll}
\hline HRU & Land-Use/Land-Cover Class & Description \\
\hline 1 & Dams & Including small farm dams and a large municipal dam \\
2 & Mountain seep wetlands & High altitude/gradient wetlands on the mountain slopes \\
3 & Palmiet wetlands & Wetlands in the valley, dominated by Prionium serratum \\
4 & Riparian vegetation & Woody vegetation in ravines, either thicket or afromontane forest \\
5 & Unproductive fynbos & Seven different unproductive fynbos and renosterveld vegetation types \\
6 & Productive fynbos & Three different productive fynbos and renosterveld vegetation types \\
7 & Degraded fynbos & Degraded by heavy grazing or altered fire regimes \\
8 & Irrigated fields & Cultivated lands with an irrigation system (sprinkler or central pivot) \\
9 & Dryland farming & Cultivated lands/agriculture that is not irrigated \\
10 & Orchards & Orchards with irrigation systems \\
11 & Acacia mearnsii & The dominant woody invasive alien plant in the catchment \\
12 & Pinus species & The second most common woody invasive alien plant in the catchment \\
13 & Other alien plants & All other woody invasive plants, mainly Eucalyptus species \\
14 & Disjunct impervious & All unnatural structures not directly connected to a watercourse \\
15 & Adjunct impervious & All unnatural structures directly connected to a watercourse \\
\hline
\end{tabular}


of South Africa) was divided into two categories according to whether the vegetation was classified as relatively productive (on relatively fertile soils), or unproductive (on highly infertile, shallow soils, mainly associated with the quartzitic sandstones in the upper regions of the catchment), or degraded by over-grazing or altered fire regimes.

Configuration. A detailed description of the model configuration as well as input data can be found in Figure S2 and Appendix S1. The HRUs were captured in a flow network, linked together in such a way that rainfall, evaporation, and riverflow in the Kromme River were represented as accurately as possible. Irrigated fields were "fed" with irrigation water from the nearest dam. Palmiet wetlands were modeled using the new $\mathrm{ACRU}_{4}$ wetland routine and a crop factor specially measured for this study (more information on the calculation of the crop factor can be found in Appendix S1).

Calibration and Validation. We evaluated the model behavior using data for the catchment as a whole and for selected HRUs. At the catchment level, we compared the outputs with results from an independent modeling study, namely the Water Resources 1990 assessment (Midgley et al. 1994) and with the best available observed data: the dam inflow data as downloaded from the Department of Water Affairs (DWA) database (http://www.dwaf.gov.za/hydrology/).

At the HRU-level, we used independent estimates of evaporation for the LULC types that changed most, namely palmiet wetlands and Acacia mearnsii (Black wattle), which we compared with the model's outputs for those HRUs. Evaporation from palmiet wetlands was measured using infrared scintillometry and also using the remote-sensing-based SEBAL model of Bastiaanssen et al. 1998 (for results, see Rebelo 2012). Measurements of evaporation from riparian invasions of $A$. mearnsii are available from a number of studies in South Africa (Dye et al. 2001; Dye \& Jarmain 2004; Clulow et al. 2011). The model initially did not provide acceptable estimates of the evaporation for these HRUs (according to available literature, sensu Table 2), but by improving soil depth input and plant characteristics, we were able to improve the model outputs.

\section{Flood Attenuation}

The responses to extreme rainfall events can still be studied using the estimated dam inflows because the magnitudes of errors in the dam inflow calculations are small relative to the volumes generated during flood events. For this analysis, we selected the 20 largest individual rainfall events in each of five decades from 1950 to 2000. The corresponding riverflow response for each rainfall event was extracted from the flow record. We used the slope of a regression fitted to the rainfall and runoff response data using STATISTICA version 10 to determine whether flood responsiveness has been affected by the LULC changes (StatSoft Inc. 2011). The significance of the differences between the correlation coefficients was determined based on the overlap of the $95 \%$ confidence intervals in a range plot.

\section{Results}

The independently modeled flow estimates all exhibit similar trends to the ACRU-modeled flow using four LULC states: 1956, 1969, 1987, and 2007 (Fig. 2). The dam inflows result in the lowest cumulative riverflow while the independently modeled riverflow (WR90) fall between them and the ACRU results. The deviations from the overall linear trend are consistent across the different models showing that there is no systematic bias in the ACRU generated riverflow. All the trend lines show that the slope from about 1993 to 1997 is steeper than other periods. The WR90 cumulative riverflow tracks the 1969 ACRU riverflow until about 1985 and then deviates progressively until 1990, probably because land-cover change was modeled progressively for the WR90 study.

The ACRU-modeled estimates of evaporation for key HRUs, palmiet wetlands, Acacia mearnsii, and fynbos, are lower than those measured in six independent studies (Table 2). However, the Kromme receives less than half the MAP of the other fynbos sites, and about $200 \mathrm{~mm}$ less than the grassland sites. The magnitude and order of the differences in evaporation that ACRU estimates for these vegetation types also matches the expectations given the differences in plant structure and water availability: A. mearnsii uses approximately $200 \mathrm{~mm}$ more than the indigenous wetland vegetation (Prionium serratum)

Table 2. Comparison of the modeled evaporation for key hydrological response units (vegetation types) from the upper Kromme (Eastern Cape) with water-use measurements from other studies in South Africa (Dye et al. 2001; Dye \& Jarmain 2004; Clulow et al. 2011). Annual evaporation outputs from the ACRU model were averaged over 50 years (from 1950 to 2000). All evaporation and rainfall (mean annual precipitation, MAP) values are reported in mm/a and means are reported \pm standard deviation. PET is estimated annual potential evaporation for the catchments and sites based on Schulze et al. 2008 (FAO Penman-Monteith method). Each biome is designated a province.

\begin{tabular}{|c|c|c|c|c|c|c|c|}
\hline Source & Location & Biome & MAP & PET & Prionium serratum & Acacia mearnsii & Fynbos \\
\hline Rebelo 2012 & Jonkershoek & Fynbos (WC) & 1,630 & 1,210 & 1,043 & - & - \\
\hline Dye \& Jarmain 2004 & Jonkershoek & Fynbos (WC) & 1,324 & 1,175 & - & 1,503 & $600-850$ \\
\hline Dye et al. 2001 & Gilboa & Grassland (KZN) & 867 & 1,149 & - & 1,260 & - \\
\hline Dye \& Jarmain 2004 & Seven-Oaks & Grassland (KZN) & 842 & 1,218 & - & 1,223 & - \\
\hline
\end{tabular}

EC, Eastern Cape; KZN, KwaZulu-Natal; and WC, Western Cape of South Africa. 


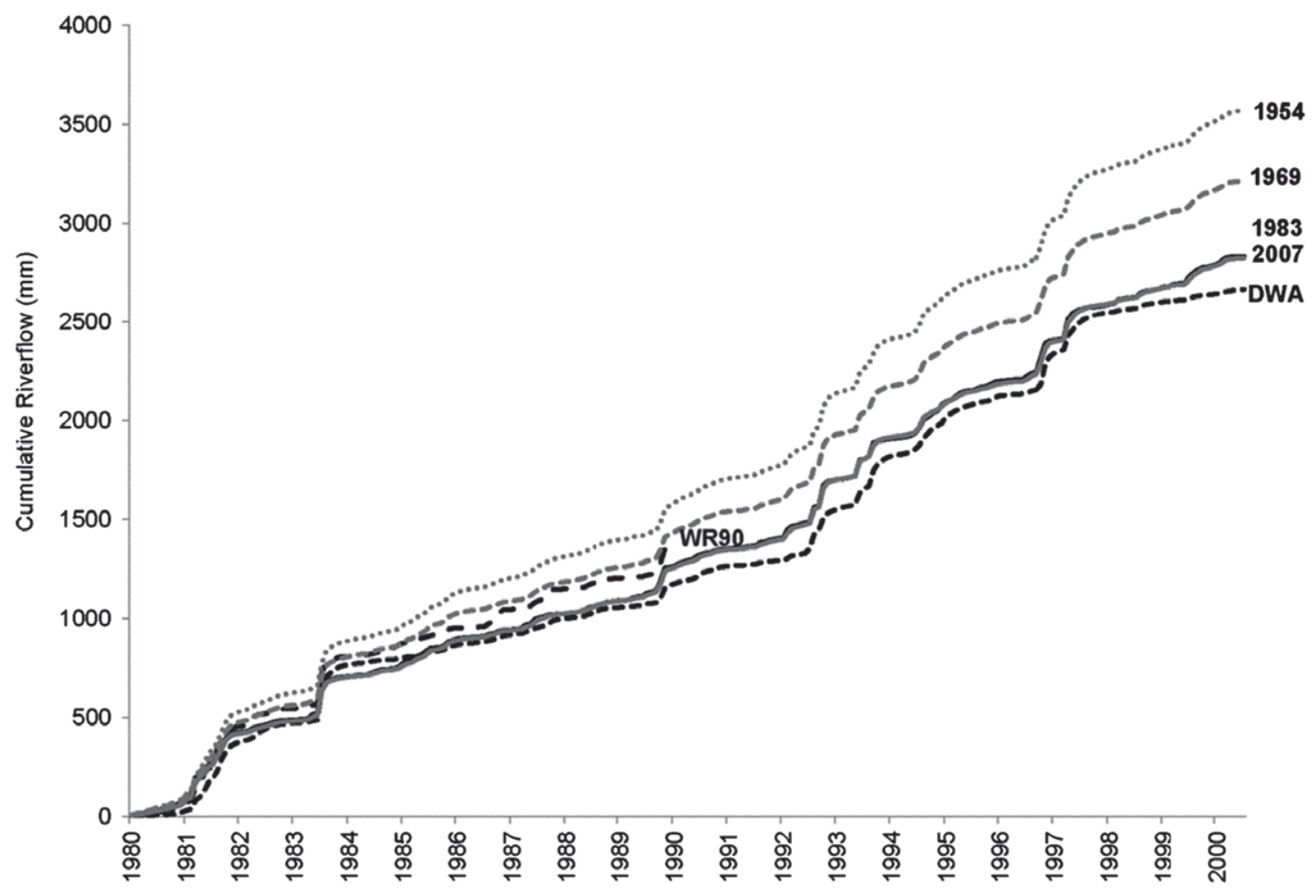

Figure 2. Modeled cumulative riverflow over 20 years in the Kromme catchment for each of the four different land-use/land-cover scenarios and for two independent modeling studies: DWA dam inflow estimates and WR90 modeled riverflow.

which, in turn, uses approximately $260 \mathrm{~mm}$ more than the dryland fynbos. The greater modeled evaporation from $A$. mearnsii versus palmiet wetlands (difference approximately $200 \mathrm{~mm}$ ) and palmiet wetlands versus dryland fynbos (difference approximately $260 \mathrm{~mm}$ ) are consistent with the findings of other hydrological studies (Table 2). The estimated potential (reference) evaporation varies between the sites but is similar to the estimates for the Jonkershoek sites and somewhat lower than that at the Wellington site, indicating that evaporative demand, a key driver of water-use for plants with access to additional water, does not differ significantly between these sites.

The greatest change in terms of magnitude in the LULC of the Kromme catchment over the past century is a $59 \%$ increase $\left(128 \mathrm{~km}^{2}\right.$ out of $\left.313 \mathrm{~km}^{2}\right)$ in the extent of degraded fynbos, due to frequent burning and grazing (Fig. 3). However, the most hydrologically significant LULC changes have occurred in the wetlands and riparian zones of the Kromme catchment. Palmiet wetlands have decreased by $84 \%$ (1,331-209 ha), mainly before 1954 and between 1954 and 1967, and riparian vegetation by $92 \%(1,649-140 \mathrm{ha})$. The loss of palmiet wetlands was largely due to the progressive spread of the invasive alien tree A. mearnsii (from 1,440 to 4,134 ha, 139 to $336 \mathrm{ha}$ within the palmiet wetlands, at a rate of $46 \mathrm{ha} / \mathrm{a}$, particularly between 1954 and 1969), and conversion of the alluvium to agriculture, both dryland (136 ha) and irrigated (307ha) (Fig. 4). The river channel and the eroded area of the palmiet wetlands increased from 73 ha in 1954 to 152 ha in 2007, almost doubling between 1983 and 2007 .
The modeled outcome was a decrease of $42 \mathrm{~mm}$ in MAR (Table 3), which corresponds to a decrease in the runoff from 26.2 to $24.6 \%$ of the rainfall. The decrease in runoff was expected given the differences in unit evaporation between $P$. serratum and $A$. mearnsii (Table 2) and the relative changes in their extent. Although the land under irrigation increased, its extent is limited compared with the changes in the areas of $P$. serratum and $A$. mearnsii, supporting the argument that invasions are the main factor accounting for the reductions.

The analysis of long-term rainfall shows that the Kromme had extended periods of above average rainfall (e.g. 1950-1970), punctuated by relatively brief but intense periods of drought (e.g. 1980-1990) (Fig. 5). The most extreme rainfall event in over 50 years in the Kromme occurred in 1983 when $332.4 \mathrm{~mm}$ fell over a period of 8 days, more than half of the catchment's mean annual rainfall $(614 \mathrm{~mm})$. Four of the 10 most extreme rainfall events occurred in the 1970s, and 2 in each of the 1950s, 1980 s, and 1990s and there were 28 rainfall events greater than $101 \mathrm{~mm}$. Overall, rainfall in this South African catchment has declined over the 50 year period (trendline equation: $y=-2.699 x+722.1, r^{2}=0.067$ ), albeit not significantly.

The relationship between rainfall and riverflow has changed over time, the catchment producing more riverflow for a given rainfall event size in each succeeding decade (Fig. 6). In the 1950 s, the slope was low (0.05) but increased to 0.89 in the $1980 \mathrm{~s}$ and then decreased to 0.66 in the 1990s. The removal of the outlier representing the largest flood event (point (a) 


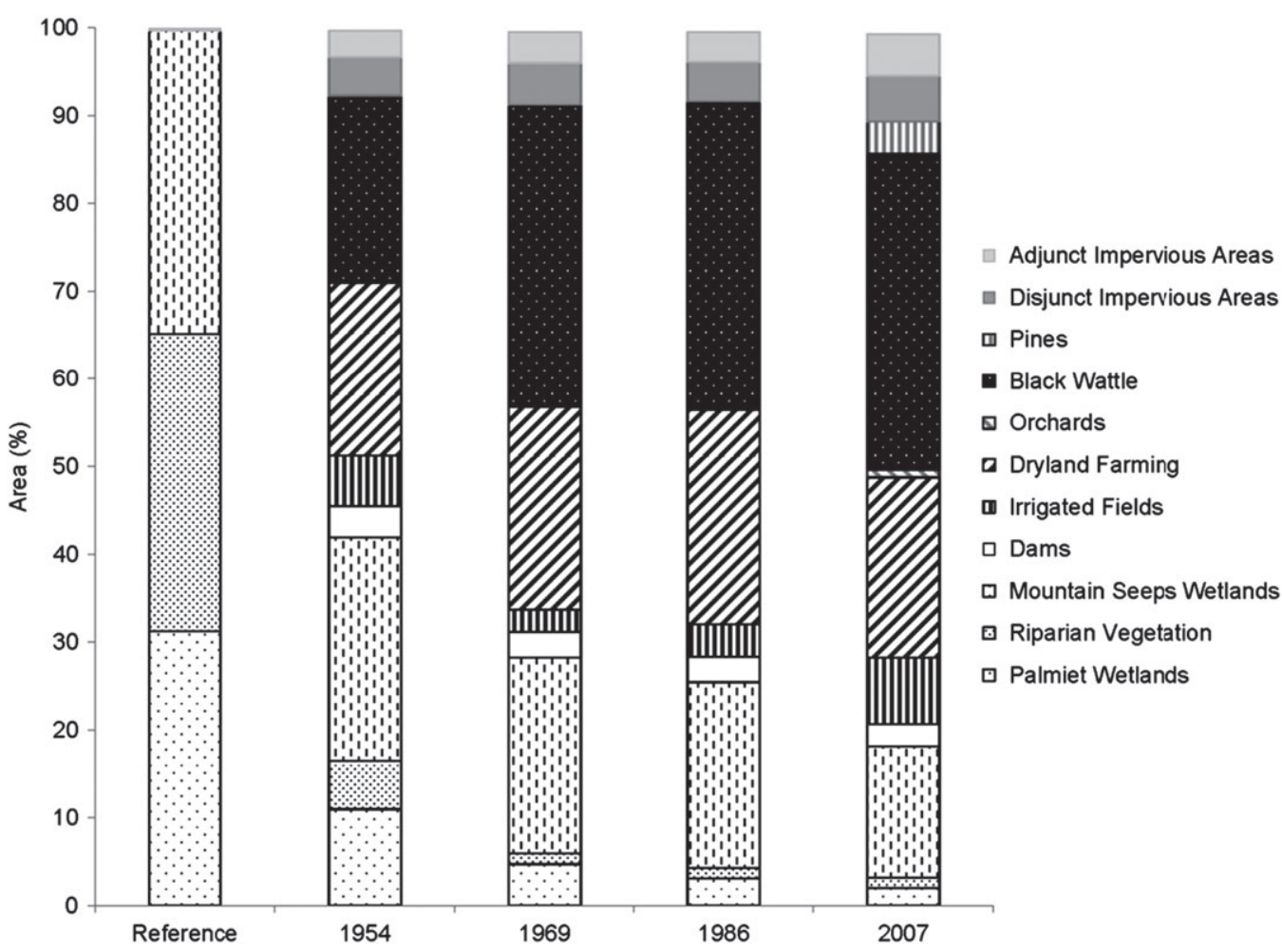

Figure 3. Land-use/land-cover (LULC) change in the Kromme over the past century (from reference conditions through three other time slices to 2007). LULC was categorized using aerial photography.

in Fig. 6) reduced the slope in the 1980 s to 0.68 , essentially the same as the slope of the 1990s. The weakest correlation coefficient was in the 1950s followed by the 1960s, but all other decades had significant correlation coefficients. The slope for the 1950s differed significantly from the rest, and that of the 1960s differed from the 1980s and 1990s (Fig. 7).

\section{Discussion}

Our results make a strong case that LULC change (woody alien plant invasion and wetland degradation) in this South African catchment has reduced water-related ecosystem services with a marked (modeled) decrease in riverflow and a significant increase in responsiveness to floods.

\section{Model Validity}

The similarity between the annual evaporation measured by independent studies, and the findings of this study at both catchment and HRU scale support the argument that the ACRU-modeled riverflow changes in the right direction given the observed changes in the extent of key LULC classes. Although the modeled evaporation for both the Acacia mearnsii and Prionium serratum HRUs is lower than measured elsewhere, the difference between them $(205 \mathrm{~mm} / \mathrm{a})$ is consistent with those between the measured values (mean $245 \mathrm{~mm} / \mathrm{a}$, range 212-460) for the four sites. The results of the flow modeling are consistent with many other studies that show that increases in woody plant cover result in flow reductions (Zhang et al. 2001). In particular, the results correspond well with the findings of Bosch and Hewlett (1982) that a 10\% change in shrub cover would change riverflow by about $10 \mathrm{~mm}$ whereas the same change in tree cover (e.g. pine, eucalyptus) would change the riverflow by approximately $40 \mathrm{~mm}$.

The fact that the modeled evaporation values were still lower than the measured ones does indicate that the ACRU riparian routines, which allow for increased water availability within the rooting zone, need to be improved. Measured evaporation of A. mearnsii is $265-600 \mathrm{~mm}$ higher than that modeled in this study (Dye et al. 2001; Dye \& Jarmain 2004; Clulow et al. 2011). By potentially underestimating groundwater availability and, thus, the water-use of both A. mearnsii and P. serratum in the Kromme River alluvium, the ACRU-modeled riverflow may underestimate the actual flow reductions.

The modeled runoff as a percentage of the rainfall is relatively high in the Kromme River, approximately $26 \%$, compared to 21 and $19 \%$ for two previous water resource assessments (Middleton \& Bailey 2008). The difference is probably largely due to the previous studies being based on an MAP of $745 \mathrm{~mm}$, $131 \mathrm{~mm}$ higher than that used in this study. The use of different models, the ACRU model (Schulze 1995) in this study and the Pitman model (Middleton \& Bailey 2008) in the water resource assessments, with their different time steps and methods of estimating key fluxes such as transpiration may also account for these differences. 

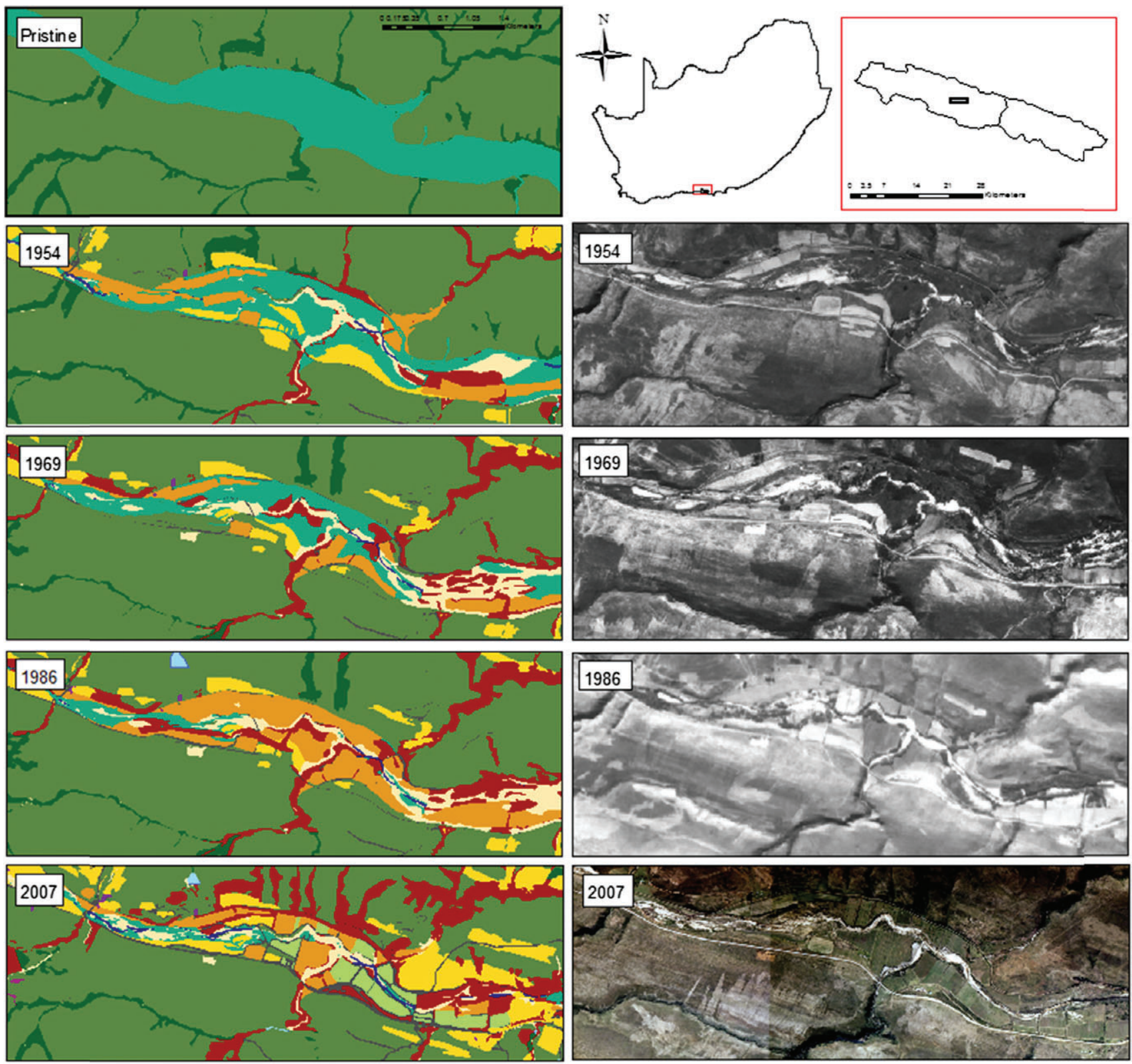

Figure 4. Land-use/land-cover (LULC) at five different times from pre-1954 (reconstructed) to 2007 showing the replacement of palmiet wetlands in the floodplains by agriculture, and the invasion of tributaries by Acacia mearnsii trees. The site is at Jagersbos farm in the upper Kromme catchment. Important LULC changes include $\square$ palmiet wetlands, $\square$ riparian vegetation, $\square$ orchards, $\square$ dryland agriculture, $\square$ irrigated agriculture, $\square$ the invasive tree Acacia mearnsii, exposed sediment (cream), $\square$ dams, and $\square$ the natural fynbos shrublands (adapted from Rebelo et al. 2013).

\section{Drivers of Changes in Water-Related Ecosystem Services}

The two main potential drivers of the apparent changes in water-related ecosystem services are climate change (i.e. changes in rainfall) and LULC change (i.e. changes in evaporation and infiltration). Because we are investigating water-related ecosystem service provision for real periods in the past, we may only infer that changes are due to LULC change, if rainfall has remained more or less constant over this period. However, while there has been a trend for rainfall to decrease over time, the trend is not significant. Therefore, the estimated decrease in riverflow is due mainly to LULC changes. This is confirmed by a sensitivity analysis using a single period of rainfall (1950-2000, mean rainfall $614 \mathrm{~mm} / \mathrm{yr}$ ); the same four LULC scenarios found that just the changes in LULC generated the same $42 \mathrm{~mm}$ decrease in runoff (Appendix S2, Table S1). In that comparison, the MAR decreased from $188 \mathrm{~mm}$ (36\% of the rainfall) for the 1954 LULC scenario to $146 \mathrm{~mm}(23.8 \%)$ for the 2007 scenario, emphasizing the overriding impacts of the increase in the extent of A. mearnsii invasions from 4 to $11 \%$ of the catchment. This increase has more than compensated for 
Table 3. Mean annual rainfall, resultant modeled riverflow and the runoff as a percentage of the rainfall in the Kromme River for four different and overlapping time periods (20 years each). Means are given \pm standard deviation.

\begin{tabular}{lcccc}
\hline $\begin{array}{l}\text { Land-Usel } \\
\text { Land-Cover }\end{array}$ & $\begin{array}{c}\text { Rainfall } \\
\text { Dates }\end{array}$ & $\begin{array}{c}\text { Mean Annual } \\
\text { Precipitation (mm) }\end{array}$ & $\begin{array}{c}\text { Mean Annual } \\
\text { Runoff (mm) }\end{array}$ & $\begin{array}{c}\text { Rainfall/ } \\
\text { Runoff(\%) }\end{array}$ \\
\hline 1954 & $1950-1970$ & $668.7 \pm 130.73$ & $175.4 \pm 96.93$ & 26.2 \\
1969 & $1960-1980$ & $617.6 \pm 169.48$ & $160.9 \pm 87.47$ & 26.1 \\
1986 & $1970-1990$ & $561.0 \pm 178.60$ & $138.5 \pm 82.10$ & 24.7 \\
2007 & $1980-2000$ & $542.6 \pm 178.70$ & $133.4 \pm 80.05$ & 24.6 \\
\hline
\end{tabular}

the effects of frequent burning and grazing of the fynbos, which is likely to increase in runoff by eliminating the tall shrub component (Bosch et al. 1986), and the loss of the palmiet wetlands and their replacement by cultivated lands which would also have increased total runoff. These findings show that LULC has been the most important driver of change in water-related ecosystem service delivery in this catchment over the past 50 years.

Acacia mearnsii is an aggressive invader of river channels and floodplains, which gives it access to water all year round. It can transpire and intercept up to $1,500 \mathrm{~mm} / \mathrm{yr}$ in riparian zones in fynbos (Dye \& Jarmain 2004). This is approximately $600 \mathrm{~mm}$ more than adjacent dryland fynbos and about $170 \mathrm{~mm}$ more than a typical fynbos (restioid) wetland (Everson et al. 1998; Dye \& Jarmain 2004). It shades out key riparian and valley-bottom wetland plant species, such as $P$. serratum. Once the native wetland plants have been displaced, the underlying peat beds are exposed, dry out, and rapidly erode. Because A. mearnsii is arguably the main driver in the destruction of the remaining palmiet wetlands, it is likely to be indirectly causing a decrease in the catchment's ability to absorb extreme rainfall events and the degradation of its water filtering service.

In contrast, the loss of the dense $P$. serratum vegetation and the underlying alluvium, and the channelization of the wetlands are predicted to have had an impact on the flow regime (water flow regulation) and, particularly, on the ability of the catchment to absorb, and respond to extreme events (i.e. its resilience) which may have offset the effects of the invasions. The region generally experiences long periods of low rainfall punctuated with periods of heavy rainfall, and often accompanied by flooding. The Kromme River is a high-energy river, so the catchment needs to have high resilience to be able to withstand and absorb the frequent, large floods. The removal of wetlands has decreased the catchment's ability to absorb extreme rainfall events, reducing its resilience and leading to severe river channel erosion (Mander et al. 2010).

When LULC change and climate change are imposed on stable ecosystems that are naturally exposed to highly variable disturbance regimes, they can react unpredictably and become exceptionally difficult to manage. In this case, conversion of the palmiet wetlands to cultivated lands which extended up to the edge of the river channel exposed the alluvium to erosion by floodwaters. Large floods scoured, deepened, and widened the river channel, washing much of the destabilized alluvium

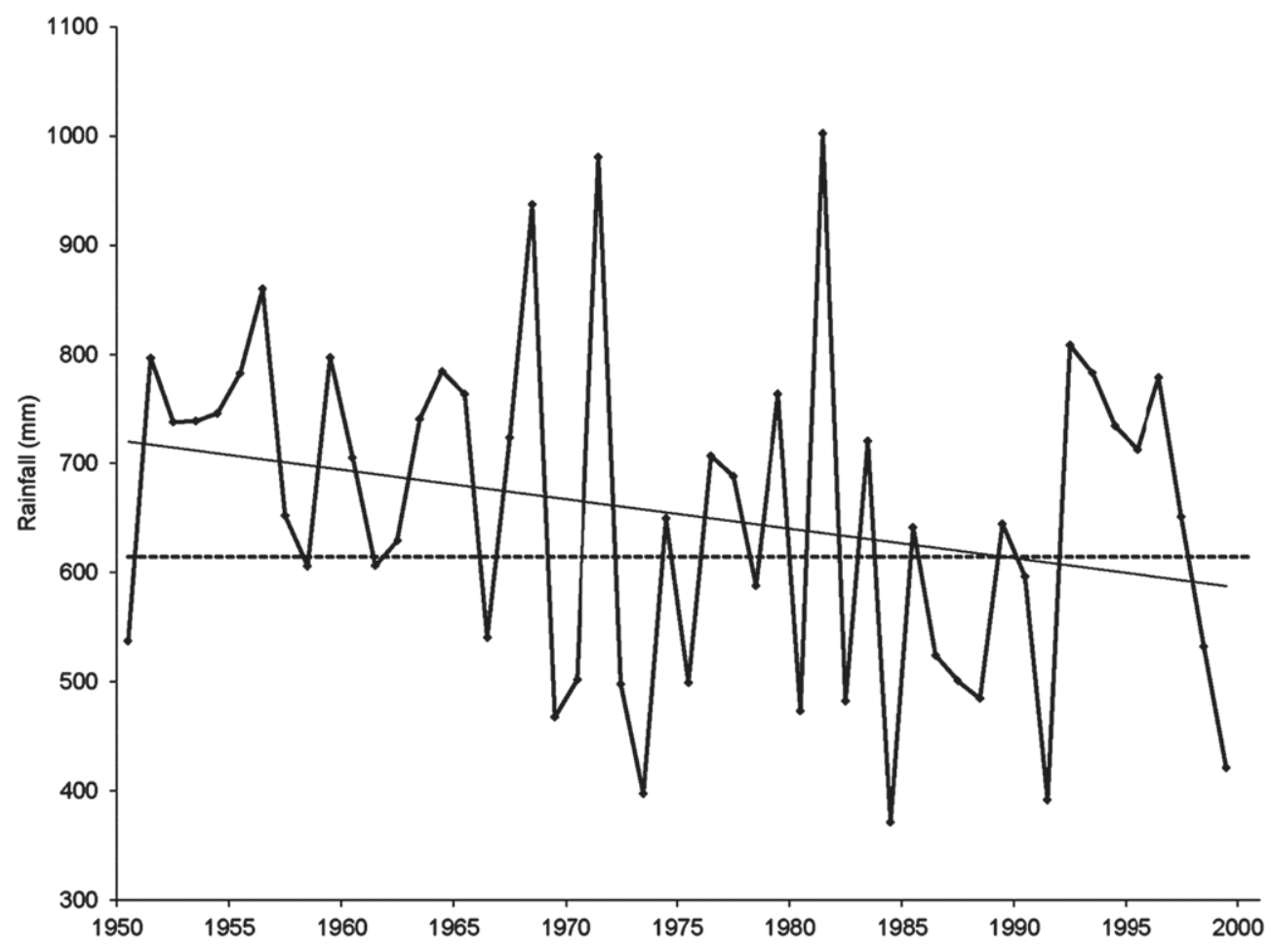

Figure 5. Mean annual rainfall for the Kromme River between 1950 and 2000 and the overall trend. The mean rainfall over 50 years is plotted as a horizontal line $(614 \mathrm{~mm})$. 


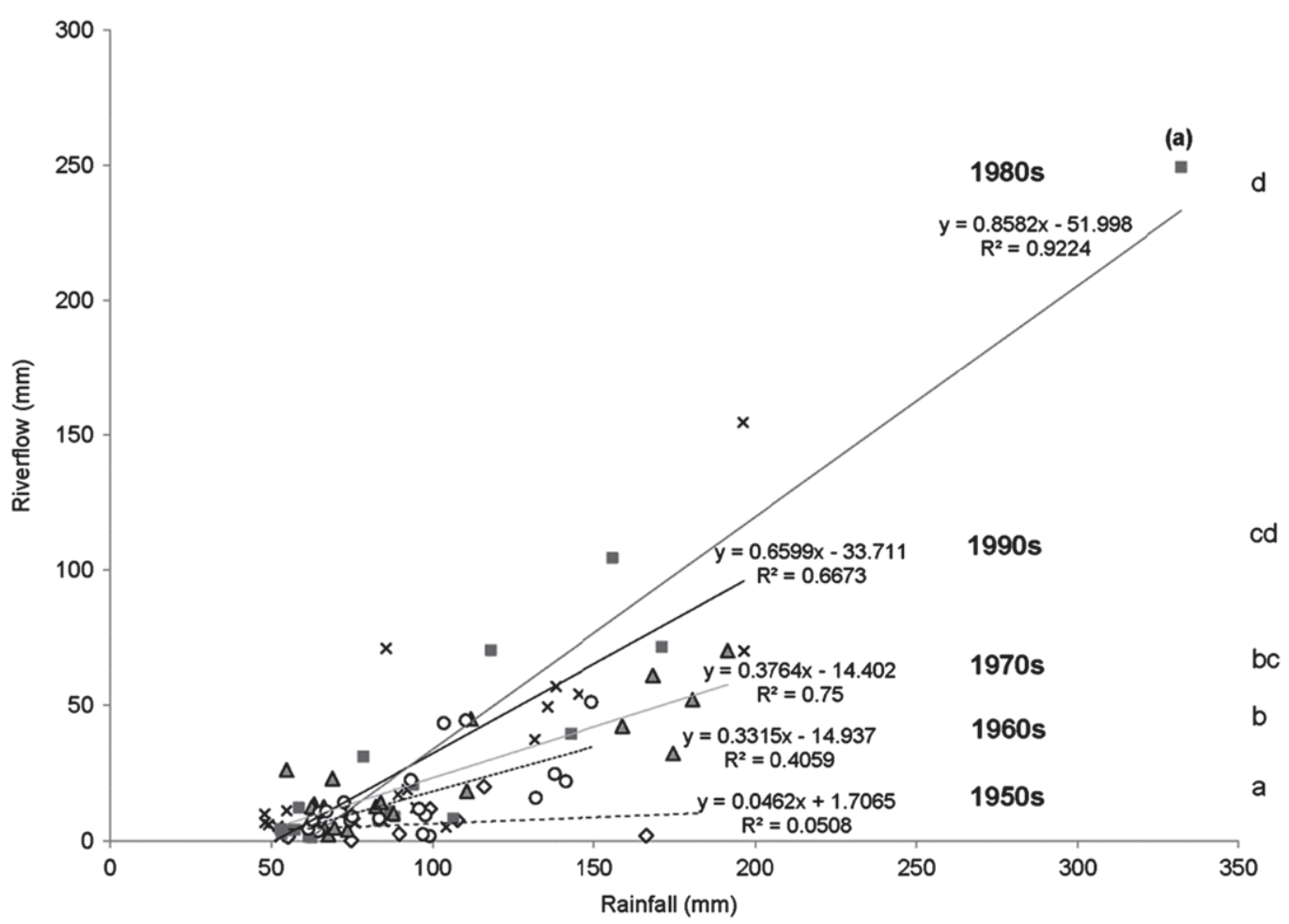

Figure 6. An assessment of the ability of the Kromme catchment to absorb and regulate water flows based on the relationship of the size of extreme rainfall events and the resulting riverflow over the past five decades. The actual dam inflow records were used in this analysis and not model outputs. Letters a-d denote significant differences between slopes.

downstream, and significantly reduced the catchment's ability to absorb floodwaters. The findings of this study present a strong argument for protecting wetlands as an insurance against future extreme rainfall events - especially in the face of uncertainties associated with anthropogenic climate change. They also make a strong case for investing in the restoration of valley-bottom wetlands, even if it is at the expense of cultivated land. Climate change studies for this particular region of South Africa project lower rainfall, more rainless days, an increase in rainfall intensity, and greater inter-annual variability (Lumsden et al. 2009), all of which make a case for rapid action.

\section{Restoration Scenarios: Ecosystem Service Trade-offs and Synergies}

If $A$. mearnsii could be cleared to the extent of its invasions in 1954 (i.e. clearing $7 \%$ or $27 \mathrm{~km}^{2}$ of the catchment), the model predicts that there would be an increase in riverflow of more than $42 \mathrm{~mm} / \mathrm{yr}$, equivalent to an increase in riverflow of 1.13 million $\mathrm{m}^{3} / \mathrm{yr}$. This increase is $6 \%$ of the Churchill Dam's supply to the Port Elizabeth Metropolitan Hub of 18.19 million $\mathrm{m}^{3} / \mathrm{yr}$ and a substantial volume of water to a city that periodically experiences severe water shortages. Furthermore, if the wetlands could be restored to the state and extent they were in the $1960 \mathrm{~s}$ (restoring $1.7 \mathrm{~km}^{2}$ ) or 1950s (restoring $5.2 \mathrm{~km}^{2}$ ), the catchment's ability to attenuate floods would be likely to improve significantly as well as decrease sediment accumulation in the dam. Our results suggest synergies between the ecosystem services of flood attenuation and water provision, supporting the findings that water-related ecosystem services are bundled (Doherty et al. 2014; Trabucchi et al. 2014). Unfortunately, some of the wetland loss will be permanent because the alluvium has been washed downstream and moving it back would be prohibitively expensive. This is a key point because, although restoration is still likely to be beneficial (due to an increase in riverflow translating to increased water supplies), restoration cannot be used as justification of further wetland degradation (Moreno-Mateos et al. 2012).

It is also apparent from our results that there is a lose-lose situation in terms of the loss of ecosystem services under undesirable LULC change (e.g. woody IAP invasion). In terms of economically desirable LULC (e.g. agriculture), there is an important trade-off between food production and water-related ecosystem services to consider. To visually represent the trade-offs and synergies between ecosystem services under different restoration scenarios in the Kromme catchment, we illustrate them in a conceptual framework adapted from (Foley et al. 2005; Fig. 7). Given that agriculture on the alluvium of the Kromme catchment is marginal, and that water regulating ecosystem services are crucial for the survival and health of a major city downstream, we would recommend that all ecosystem services are given full consideration by managers and decision makers involved, and that LULC decisions are no longer based primarily on maximization of a single ecosystem service (e.g. food provision). 

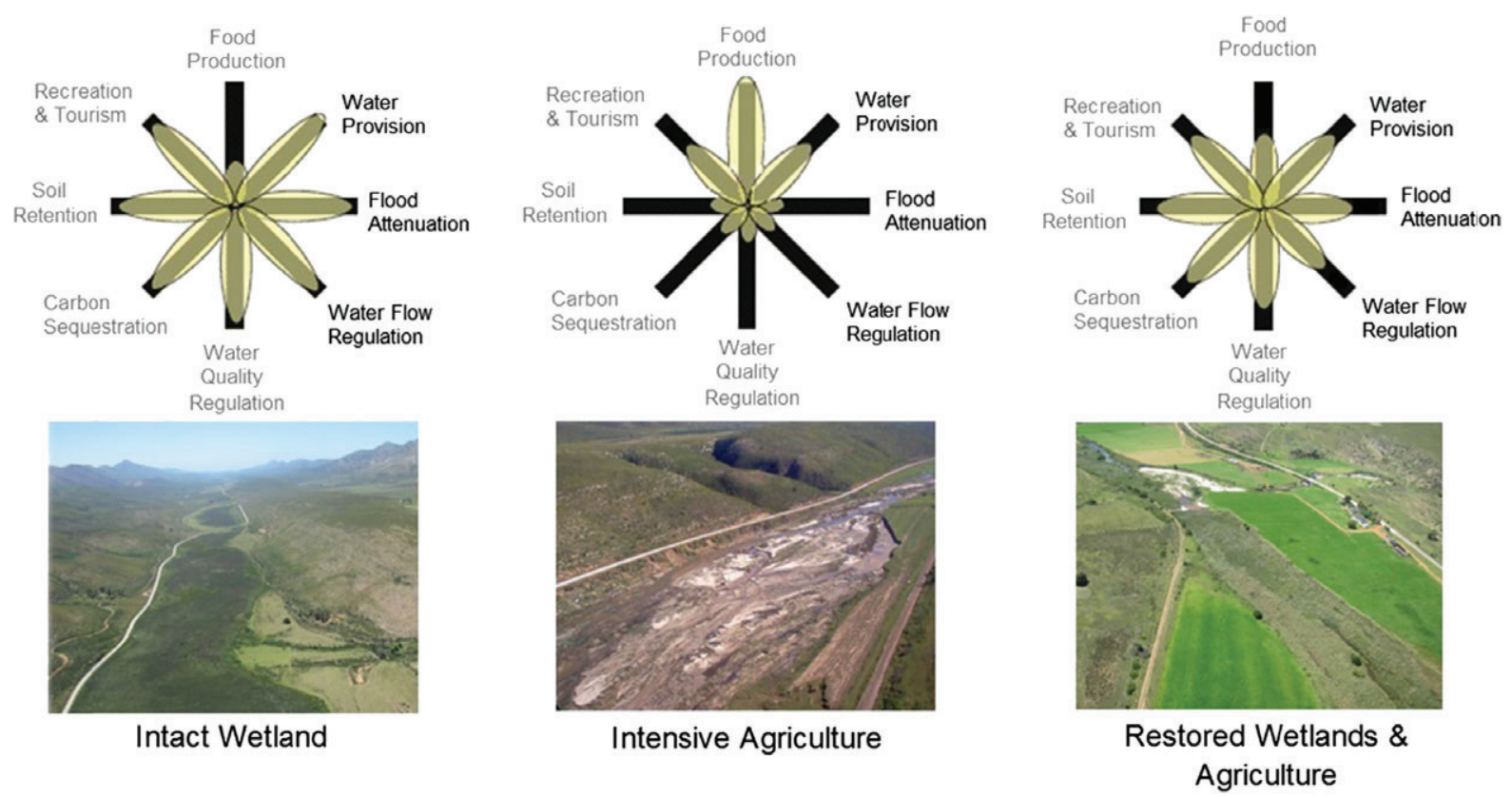

Figure 7. A conceptual representation of the trade-offs and synergies of different ecosystem services relevant to the Kromme River System, South Africa. Ecosystem services in black font are those quantified in this study, others that are important, but beyond the scope of this study are in gray. Three LULC scenarios are considered: a relatively intact wetland (e.g. scenario pre-1954), intensive agriculture replacing the wetland and leading to loss of alluvium (e.g. scenario 1986), and an intermediate scenario where agriculture on the alluvium ceases and active restoration has been completed (e.g. scenario 1969) (adapted from Foley et al. 2005). Center photo by P. Joubert, others by author.

We further recommend that areas crucial for the provision of water-related ecosystem services (e.g. the historical alluvium), be zoned for this purpose exclusively, and that marginal agriculture be relocated to other less sensitive locations. However, we recognize that this change would be a complex procedure, involving interdisciplinary teams, stakeholder engagement, incentives for landowners, and strong governance and institutional support (Cowling et al. 2008; Polasky et al. 2014). The results of such an undertaking have been shown to be beneficial, for example the Catskill Catchment, an important water-providing catchment for New York City, was preserved for its water quality ecosystem service, negating the need for a water filtration plant, which saved billions of dollars in the long-term (Foran et al. 2000; Postel \& Thompson 2005).

It is important to understand the relationship between spatial LULC patterns and hydrological ecosystem processes, as this knowledge can shape restoration priorities and management plans for valuable water-providing catchments worldwide. Key LULC changes have resulted in the degradation of the ecological infrastructure of a South African catchment, resulting in an overall decline in water provision and a reduction in flood attenuation. The quantified hydrological value of this ecological infrastructure makes a strong case for the protection and restoration of wetlands, as well as a foundation for economic valuation whereupon payments for these services can be built. In the face of climate change and uncertainty around how ecosystems will react, it is essential that valuable water-providing systems such as the Kromme River are restored and managed so that an acceptable degree of resilience is preserved.

\section{Acknowledgments}

The South African Water Research Commission provided funding for this research through ASSET Research in Key Strategic Area 4: Water-use in Agriculture. We wish to acknowledge the following people for their support during the research: Mr J. Buckle, Prof M. Kidd, Dr C. Jarmain, Mr M. Horan, Mr S. Thornton-Dibb, the farmers of the Upper Kromme River and LivingLands (www.livinglands.co.za).

\section{LITERATURE CITED}

Ashton PG (2002) Avoiding conflicts over Africa's water resources. Ambio 31:236-242

Bastiaanssen WGM, Menenti M, Feddes RA, Holtslag AAM (1998) A remote sensing surface energy balance algorithm for land (SEBAL) 1. Formulation. Journal of Hydrology 212-213:198-212

Bosch JM, Hewlett JD (1982) A review of catchment experiments to determine the effect of vegetation changes on water yield and evapotranspiration. Journal of Hydrology 55:3-23

Bosch JM, van Wilgen BW, Bands DP (1986) A model for comparing water yield from fynbos catchments burnt at different intervals. Water SA 12:191-196

Clulow AD, Everson CS, Gush MB (2011) The long-term impact of Acacia mearnsii trees on evaporation, streamflow, and ground water resources. Report Number TT505/11, Water Research Commission, Pretoria, South Africa. http://www.wrc.org.za/ (accessed 23 June 2015)

Cowling RM, Egoh B, Knight AT, Farrell PJO, Reyers B, Rouget M, Roux DJ, Welz A, Wilhelm-Rechman A (2008) An operational model for mainstreaming ecosystem services for implementation. PNAS 105:9483-9488

Doherty JM, Miller JF, Prellwitz SG, Thompson AM, Loheide SP II, Zedler JB (2014) Hydrologic regimes revealed bundles and tradeoffs among six wetland services. Ecosystems 17:1026-1039 
DWA (Department of Water Affairs, South Africa) (2010) Algoa Reconciliation Strategy. Prepared by E van der Berg and Dr MJ Shand of Aurecon South Africa (Pty) Ltd, as part of the Water Reconciliation Strategy Study for the Algoa Water Supply Area. Department of Water Affairs, Pretoria, South Africa. DWA Report No. WMA15/M00/00/1409/04. https://www.dwa.gov.za (accessed 23 June 2015)

Dye P, Jarmain C (2004) Water use by black wattle (Acacia mearnsii): implications for the link between removal of invading trees and catchment streamflow response. South African Journal of Science 100:40-44

Dye PJ, Moses G, Vilakazi P, Ndlela R, Royappen M (2001) Comparative water use of wattle thickets and indigenous plant communities at riparian sites in the Western Cape and KwaZulu-Natal. Water SA 27:529-538

ESRI (Environmental Systems Resource Institute) (2009) ArcMap 9.2. ESRI, Redlands, California

Everson CS, Gush MB, Moodley M, Jarmain C, Govender M, Dye P (2007) Effective management of the riparian zone vegetation to significantly reduce the cost of catchment management and enable greater productivity of land resources. Report Number 1284/1/07, Water Research Commission, Pretoria, South Africa. http://www.wrc.org.za (accessed 23 June 2015)

Everson CS, Molefe GL, Everson TM (1998) Monitoring and modelling components of the water balance in a grassland catchment in the summer rainfall area of South Africa. Report Number 493/1/98, Water Research Commission, Pretoria, South Africa. http://www.wrc.org.za (accessed 23 June 2015)

Foley JA, Defries R, Asner GP, Barford C, Bonan G, Carpente SR, et al. (2005) Global consequences of land use. Science 309:570-574

Foran J, Brosnan T, Connor M, Delfino J, DePinto J, Dickson K, et al. (2000) A framework for comprehensive, integrated, waters monitoring in New York City. Environmental Monitoring and Assessment 62:147-167

Gray RP (2011) Techniques for assessing the impacts of wetlands on hydrological responses under varying climatic conditions. MSc dissertation. University of KwaZulu-Natal, Durban, South Africa

Hamilton SK (2012) Biogeochemical time lags may delay responses of streams to ecological restoration. Freshwater Biology 57:43-57

Iverson L, Echeverria C, Nahuelhual L, Luque S (2014) Ecosystem services in changing landscapes: an introduction. Landscape Ecology 29:181-186

Jewitt GPW, Schulze RE (1999) Verification of the ACRU model for forest hydrology applications. Water SA 25:483-489

Le Maitre DC, Görgens A (2001) Potential impacts of invasive alien plants on reservoir yields in South Africa. Tenth South African National Hydrology Symposium, Cape Town, South Africa, 26-28 September 2001

Le Maitre DC, Scott DF, Colvin C (1999) A review of information on interactions between vegetation and groundwater. Water SA 25:137-152

Le Maitre DC, van Wilgen BW, Chapman RA, McKelly DH (1996) Invasive plants and water resources in the Western Cape Province, South Africa: modelling the consequences of a lack of management. Journal of Applied Ecology 33:161-172

Lumsden TG, Schulze RE, Hewitson BC (2009) Evaluation of potential changes in hydrologically relevant statistics of rainfall in Southern Africa under conditions of climate change. Water SA 35:649-656

Lynch SD (2003) Development of a raster database of annual, monthly and daily rainfall for Southern Africa. WRC Report 1156/1/03, Water Research Commission, Pretoria, South Africa. Pages 78. http://www.wrc.org.za (accessed 23 June 2015)

Mander M, Blignaut J, Van Niekerk M, Cowling R, Horan M, Knoesen D, Mills A, Powell M, Schulze R (2010) Baviaanskloof-Tsitsikamma payments for ecosystem services: a feasibility assessment. https://www.cbd.int (accessed 23 June 2015)

MEA (Millennium Ecosystem Assessment) (2005) Ecosystems and human well-being: synthesis. Island Press, Washington, D.C.

Middleton BJ, Bailey AK (2008) Water resources of South Africa, 2005 study (WR2005). WRC Report Number TT 380/08. Water Research Commission, Pretoria, South Africa. http://www.wrc.org.za (accessed 23 June 2015)

Midgley DC, Pitman WV, Middleton BJ (1994) Surface Water Resources of South Africa 1990 Volume III: Orange-Namaqualand. Report 1990
298/3.1/94. Water Research Commission, Pretoria, South Africa. http:// www.wrc.org.za/ (accessed 23 June 2015)

Moreno-Mateos D, Power ME, Comin FA, Yockteng R (2012) Structural and functional loss in restored wetland ecosystems. PLoS Biology 10:e1001247

Nel JL, Driver A (2012) South African National Biodiversity Assessment 2011: Technical Report. Volume 2: Freshwater Component. CSIR Report Number CSIR/NRE/ECO/IR/2012/0022/A. Council for Scientific and Industrial Research, Stellenbosch, South Africa. bgis.sanbi.org (accessed 23 June 2015)

Nel JL, Roux DJ, Maree G, Kleynhans CJ, Moolman J, Reyers B, Rouget M, Cowling RM (2007) Rivers in peril inside and outside protected areas: a systematic approach to conservation assessment of river ecosystems. Biodiversity Research 13:341-352

Nelson GC (2005) Drivers of ecosystem change: summary chapter. Millennium ecosystem assessment. Pages 73-76. In: Hassan R, Scholes R, Ash N (eds) Ecosystems and human well-being: current state and trends. Vol. 1. Island Press, Washington, D.C. www.unep.org (accessed 23 June 2015)

Ollis DJ, Snaddon CD, Job NM, Mbona M (2013) Classification system for wetlands and other aquatic ecosystems in South Africa. User manual: inland systems. SANBI biodiversity series 22. South African National Biodiversity Institute, Pretoria, South Africa. www.sanbi.org (accessed 23 June 2015)

Polasky S, Lewis DJ, Plantinga AJ, Nelson E (2014) Implementing the optimal provision of ecosystem services. PNAS 111:6248-6253

Postel S, Thompson B (2005) Watershed protection: capturing the benefits of nature's water supply services. Natural Resources Forum 29:98-108

Rebelo AJ (2012) An ecological and hydrological evaluation of the effects of restoration on ecosystem services in the Kromme River System, South Africa. MSc dissertation. Stellenbosch University, Stellenbosch, South Africa. http://hdl.handle.net/10019.1/71967 (accessed 23 June 2015)

Rebelo AJ, Le Maitre DC, Esler KJ, Cowling RM (2013) Are we destroying our insurance policy? The effects of alien invasion and subsequent restoration: a case study of the Kromme River System, South Africa. Pages 335-364. In: Fu B, Jones KB (eds) Landscape ecology for sustainable environment and culture. Springer, Dordrecht, Netherlands

Reyers B, O'Farrell PJ, Cowling RM, Egoh BN, Le Maitre DC, Vlok JHJ (2009) Ecosystem services, land-cover change, and stakeholders: finding a sustainable foothold for a semi-arid biodiversity hotspot. Ecology and Society 14:38-61

Russi D, ten Brink P, Farmer A, Badura T, Coates D, Förster J, Kumar R, Davidson N (2013) The Economics of Ecosystems and Biodiversity for Water and Wetlands. IEEP, London, U.K. and Brussels, Belgium; Ramsar Secretariat, Gland, Switzerland. www.ramsar.org (accessed 23 June 2015)

Scanlon BR, Jolly I, Sophocleus M, Zhang L (2007) Global impacts of conversions from natural to agricultural ecosystems on water resources: quantity versus quality. Water Resources Research 43:W03437

Schulze RE (1995) Pages 552. Hydrology and agrohydrology: a text to accompany the ACRU 3.00 Agrohydrological Modelling System. Water Research Commission, Pretoria, South Africa

Schulze RE, Maharaj M, Warburton ML, Gers CJ, Horan MJC, Kunz RP, Clark DJ (2008) Electronic data accompanying the South African Atlas of Climatology and Agrohydrology. Report: 1489/1/08, Water Research Commission, Pretoria, South Africa. http://www.wrc.org.za/ (accessed 23 June 2015)

Scott DF (1999) Managing riparian zone vegetation to sustain streamflow: results of paired catchment experiments in South Africa. Canadian Journal of Forestry Research 29:1149-1157

Scott DF, Bruijnzeel LA, Vertessy RA, Calder IR (2004) Impacts of forest plantations on streamflow. Forest Hydrology 272:1-11

Scott DF, Lesch W (1997) Streamflow responses to afforestation with Eucalyptus grandis and Pinus patula and to felling in the Mokobulaan experimental catchments, Mpumalanga province. South African Journal of Hydrology 199:360-377

Scott DF, Smith RE (1997) Preliminary empirical models to predict reductions in total and low flows resulting from afforestation. Water SA 23:135-140 
Sieben EJJ (2012) Plant functional composition and ecosystem properties: the case of peatlands in South Africa. Plant Ecology 213:809-820

Simonit S, Perrings C (2011) Sustainability and the value of the 'regulating' services: wetlands and water quality in Lake Victoria. Ecological Economics 70:1189-1199

Skead CJ (2009) Historical plant incidence in southern Africa. Strelitzia 24. South African National Biodiversity Institute, Pretoria, South Africa

Smith P, Ashmore MR, Black HIJ, Burgess PJ, Evans CD, Quine TA, Thomson AM, Hicks K, Orr HG (2013) The role of ecosystems and their management in regulating climate, and soil, water and air quality. Journal of Applied Ecology 50:812-829

StatSoft Inc. (2011) STATISTICA data analysis software system, version 10, Tulsa, Oklahoma

Trabucchi M, Farrell PJO, Notivol E, Comin FA (2014) Mapping ecological processes and ecosystem services for prioritizing restoration efforts in a semi-arid Mediterranean River basin. Environmental Management 53:1132-1145

Van der Biest K, Hondt RD, Jacobs S, Landuyt D, Staes J, Goethals P, Meire P (2014) EBI: an index for delivery of ecosystem service bundles. Ecological Indicators 37:252-265

Vertessy RA, Zhang L, Dawes WR (2003) Plantations, river flows and river salinity. Australian Forestry 66:55-61

Vörösmarty CJ, Lévêque C, Revenga C (2005) Chapter 7. Fresh water. Pages 165-207. In: Hassan R, Scholes R, Ash N (eds) Ecosystems and human well-being: current state and trends. Vol. 1. Island Press, Washington, D.C. www.unep.org (accessed 23 June 2015)

Warburton M, Schulze RE, Jewitt GPW (2010) Confirmation of ACRU model results for applications in land use and climate change studies. Hydrology and Earth System Science 14:2399-2414

van Wilgen BW, le Maitre DC, Wannenburgh A, Kotze IM, van den Berg L, Henderson L (2012) An assessment of the effectiveness of a large, national-scale invasive alien plant control strategy in South Africa. Biological Conservation 148:28-38

Xu Y, Lin L, Jia H (2009) Groundwater Flow Conceptualization and Storage Determination of the Table Mountain Group (TMG) Aquifers. Report

Coordinating Editor: Darren Ryder
No. 1419/1/09, Water Research Commission, Pretoria, South Africa. http://www.wrc.org.za (accessed 23 June 2015)

Zhang L, Dawes WR, Walker GR (2001) Response of mean annual evapotranspiration to vegetation changes at catchment scale. Water Resources Research $37: 701-708$

\section{Supporting Information}

The following information may be found in the online version of this article:

Appendix S1. Data sources.

Appendix S2. Sensitivity analysis.

Figure S1. These photographs of the Kromme catchment were taken by the author from a helicopter in 2011. (A) An aerial view down the catchment showing a pristine remnant of a palmiet wetland threatened by a regional road on the left and agriculture on the alluvial fans to the right. (B) Another aerial view of the catchment, showing agricultural fields and orchards lying abandoned due to damage and bankruptcy following devastating floods in the 1980s. (C) Wetland restoration by means of a weir to stop erosion. The wetland can be seen recovering behind the weir. (D) Active agriculture in the floodplains and illegal straightening and channelization of the river. (E) A weir further down the catchment with the restored wetland recovering behind it. Agriculture (grazing) can be seen on the floodplain on either side of the remaining strip of wetland. (F) An unrecognizable river: a lower section of the Kromme River where Acacia mearnsii trees have shaded out the palmiet (Prionium serratum) and invaded the floodplain and tributaries.

Figure S2. The 11 subcatchments of the upper Kromme River were routed to form a hydrological network. Within each subcatchment, the 15 HRUs were configured according to the above design.

Figure S3. Mean monthly rainfall from 1950 to 2000 driving the three subcatchment segments: A1-4, B1-4, and B5-7. Gauges are placed at Hendrikskraal $\mathbf{\square}$, the town of Kareedouw $\square$, and at the Churchill Dam $\square$. Data are means and standard deviations. Table S1. Modeled riverflow (mean annual runoff: MAR) for the Kromme catchment for four different land-use/land-cover (LULC) scenarios over 50 years. LULC scenarios were modeled along a degradation gradient, from (1) least degraded to (4) most degraded. Rainfall input data, based on the 50-year mean $(614.0 \pm 165.56)$, were identical for each scenario. Means are given \pm standard deviation.

Received: 5 March, 2015; First decision: 5 May, 2015; Revised: 6 June, 2015; Accepted: 6 June, 2015 